\title{
Author Index Volume 8, 2015
}

Agbor, Avitus 145

Appiagyei-Atua, Kwadwo 209

Bu, Qingxiu 33

Chitimira, Howard 183

Ezennia, Celestine Nchekwube 115

Kiyani, Asad 1

Klaaren, Jonathan 174

Magnet, Joseph Eliot 237

Wabwile, Nyongesa Michael 87 